\title{
How we do it: Laparoscopic cholecystectomy in patients with severe obesity
}

\author{
Thomas B. Russell(D), Somaiah Aroori(D) \\ Clinic of Hepatopancreaticobiliary Surgery, University Hospitals Plymouth NHS Trust, Plymouth, United Kingdom
}

\begin{abstract}
The number of patients with obesity is set to rise, as is the proportion with severe obesity. These patients are a high-risk subgroup who present additional challenges to the surgeon when performing laparoscopic cholecystectomy. It is important that all surgeons who perform this procedure have a safe strategy they can revert to. This article outlines our approach. After obtaining pneumoperitoneum via a supra-umbilical incision, we advise placing a fascial suture before proceeding with the operation. This allows for high-quality closure, reduces the incidence of incisional hernia, and reduces the risk of inadvertent bowel injury. We also advise the repositioning of the patient on the operating table prior to port placement such that an ergonomic set-up can be achieved. In addition to standard ports, we use an additional twelve-millimetre port in the left upper quadrant. A fan retractor can be inserted via this port and used to gently retract the duodenum inferiorly. This provides adequate exposure for Calot's dissection and arguably reduces the risk of injury to a fatty liver. This technique can also be used in non-obese patients in whom Calot's dissection is particularly challenging, for instance in those who undergo delayed cholecystectomy.
\end{abstract}

Keywords: Laparoscopic cholecystectomy, obese, morbid, severe, bariatric, day case surgery

Cite this article as: Russell TB, Aroori S. How we do it: Laparoscopic cholecystectomy in patients with severe obesity. Turk J Surg 2021; 37 (4): 413-416.

\section{Corresponding Author}

Somaiah Aroor

E-mail: s.aroori@nhs.net

Received: 29.07 .2021

Accepted: 29.09.2021

Available Online Date: 31.12 .2021

( Copyright 2021 by Turkish Surgical Society Available online at www.turkjsurg.com

DOI: $10.47717 /$ turkjsurg.2021.5452

\section{INTRODUCTION}

The first cholecystectomy was performed by Carl Langenbuch in Germany in 1882 (1). It was over a hundred years later, in 1985, when Erich Mühe performed the first laparoscopic cholecystectomy (LC) also in Germany (1). Despite early scepticism surrounding the technique, LC was the gold standard by the mid-1990s. In the UK, it is commonly performed as a day case procedure in low-risk patients, and the rate of conversion to open surgery is less than $4 \%$ (2).

Obesity is a growing public health problem, particularly in the Western world. Currently, 28.0\% of adults in England are obese (body mass index (BMI) $\geq 30 \mathrm{~kg} / \mathrm{m}^{2}$ ) and $3.3 \%$ have severe, or class III obesity (BMI $\geq 40 \mathrm{~kg} / \mathrm{m}^{2}$ ) (3). These figures are set to rise; it is predicted that 8.0\% of adults in England will be severely obese in 2035 (3). Whilst high BMI was once considered a relative contra-indication, recent studies have confirmed that LC can be performed safely in patients with obesity or severe obesity (4). However, patient with severe obesity presents a unique set of technical challenges which all surgeons must be prepared to manage. This article outlines our strategy. Verbal informed consent was obtained from the patient whose images were used. No patient identifiable data/images were included for the purposes of confidentiality. The techniques discussed may also be used in non-obese patients in whom Calot's dissection is particularly challenging.

\section{How We Do It}

The approach outlined below can be utilised in patients with severe obesity or patients in whom Calot's dissection is challenging, for instance male patients with central obesity and those with Mirizzi syndrome. The only additional piece of surgical equipment required is a fan retractor. The patient should be positioned supine, in the standard manner. Particular attention should be paid to how the patient is secured since a severely obese patient is at high-risk of sliding off the table when it is rotated; additional shoulder and left-sided support is advised. Since this group of 
patients is also at high-risk of post-operative venous thromboembolism, intra-operative calf compression pumps should be used, and a single dose of low molecular weight heparin should be considered post-operatively. After prepping, drapes should be placed to achieve maximum abdominal exposure. The left sided drapes should be placed as low as is feasible.

Pneumoperitoneum should be obtained in the standard manner using Hassan's technique. It is advisable to make the initial incision superior to the umbilicus so reaching the right upper quadrant does not become a struggle. Once pneumoperitoneum is obtained, we advise placing a fascial suture before continuing with the operation. This allows for good quality closure in a patient who is at high-risk of incisional hernia, and also reduces the risk of the surgeon inadvertently catching the bowel and not being aware of this. We advise re-positioning the patient at this point so that optimum port placement is obtained. "Head up" and "right side up" will help displace the small bowel and omentum such that the gallbladder is easily accessible.

A ten-millimetre port can then be placed below the xiphoid sternum and inserted under direct vision. The tip of the trocar should be directed towards the apex of an open triangle formed by the junction of segment III, segment VIb and the falciform ligament (Aroori's triangle). The tip can then pierce the falciform ligament and be directed towards the gallbladder. An additional five-millimetre port is then placed as laterally as possible in the right upper quadrant, inferior to the lateral right ribs. A final 5 millimetre port is placed between the 10 millimetre ports which have already been placed. This should roughly be in-line with the gallbladder in the midclavicular line. These ports should not be placed directly beneath the inferior surface of the right ribs as this will create an angle which makes accessing the gallbladder more challenging. A gap of at least two finger breadths should be left. In addition to the standard ports mentioned, we advise the use of a fifth port in the severely obese patient (Figure 1). A twelve-millimetre port should be placed in the left upper quadrant and angled towards the gallbladder (Figure 2).

As is standard, the assistant should grab the fundus of the gallbladder with a grasping instrument and gently lift it over the edge of the liver towards the right shoulder. Using the screen as a clock face, the assistant should retract the fundus of the gallbladder towards the eleven o'clock position. This alone usually provides adequate exposure for the lead surgeon to continue with the dissection safely. However, in the severely obese patient it may not be possible to proceed due to limited space and poor views (Figure 2). Some surgeons are tempted to have the assistant push up aggressively on their instrument or to try to push the liver superiorly with an open grasping instrument. We argue that this greatly increases the risk of injury to the liver which is likely to be fatty and friable. We suggest it is safer to insert a fan retractor via the additional port and to gently re-

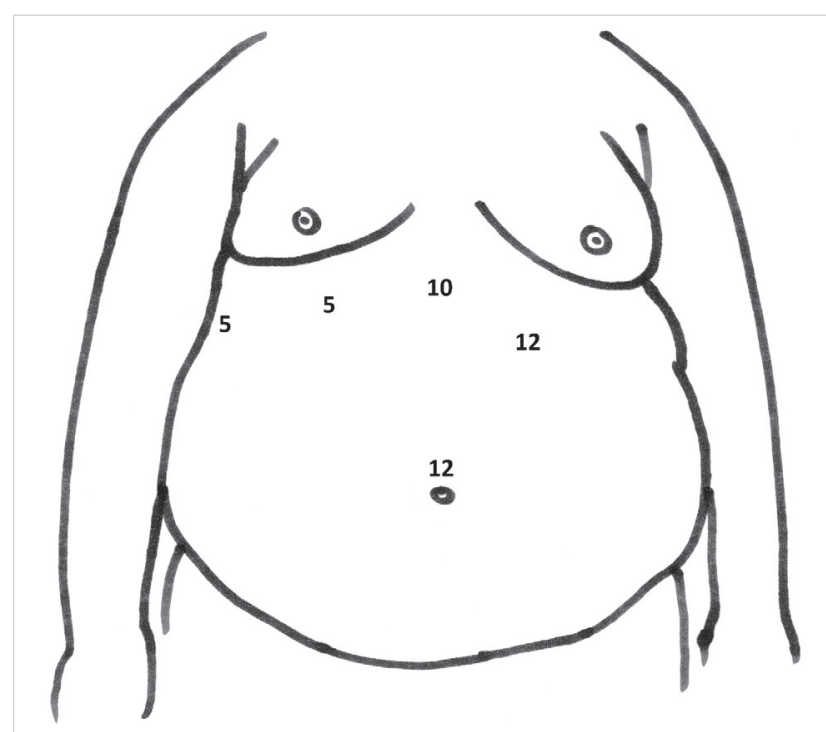

Figure 1. Port placement for laparoscopic cholecystectomy in a male patient with severe obesity. We advise a supra-umbilical initial incision and an additional twelve-millimetre port in the left upper quadrant. The five-millimetre ports should not be placed directly under the rib cage as this result in a more challenging angle and difficulties accessing the gallbladder.

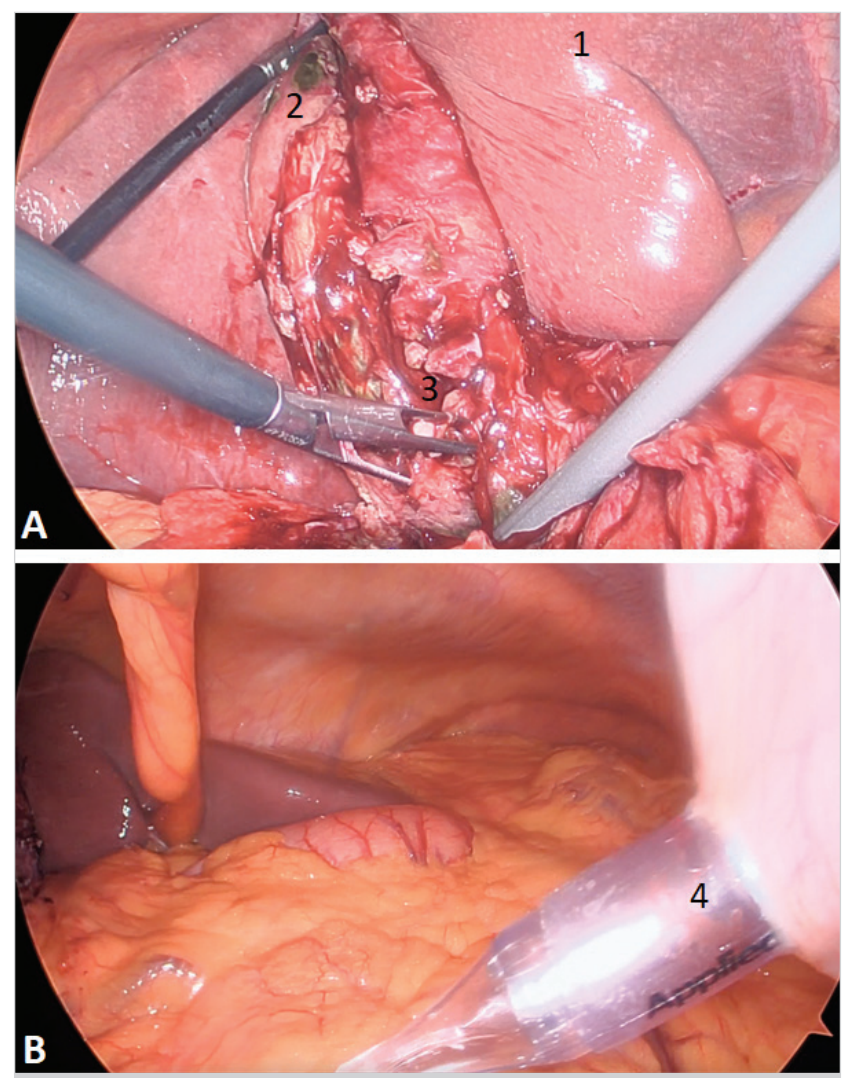

Figure 2. A. The challenging initial dissection in a male patient with severe obesity. 1 = liver, 2 = gallbladder fundus retracted superiorly, 3 $=$ Calot's triangle difficult to appreciate. B. The additional port placed in the left upper quadrant. 4 = additional port. 


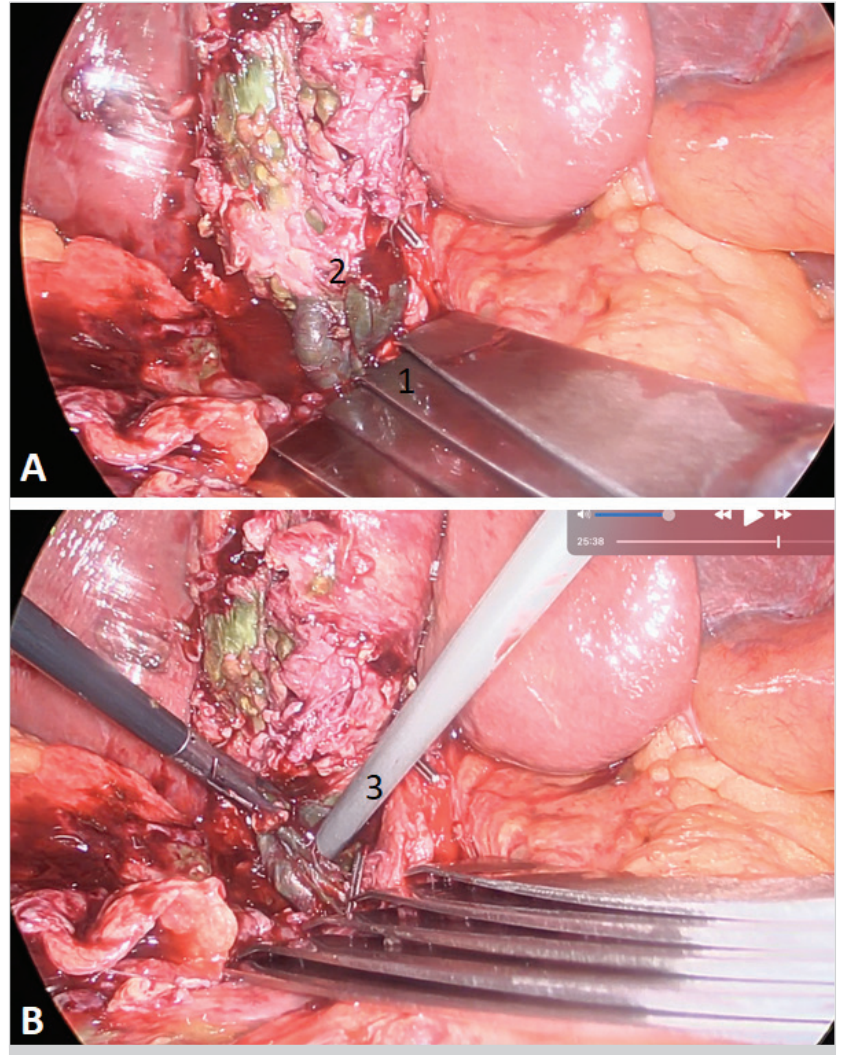

Figure 3. A. Downward retraction on the duodenum using a fan retractor (1) allows a clear view of the structures which need to be dissected (2) so that the critical view can be obtained. Controlled use of a suction device (3) allows safe dissection of Calot's triangle.

tract the duodenum (D1) inferiorly (Figure 3). Since the tip of a fan retractor is blunt, the risk of injury to the duodenum is minimal. This technique can also be used in other cases where the gallbladder cannot be safely retracted upwards towards the right shoulder tip e.g. where Hartmann's pouch is adhered to the hepatoduodenal ligament or where a severely inflamed gallbladder results in difficult dissection.

The operation can then proceed. We advise that dissection is commenced on the back of the gallbladder, at the seven or eight o'clock position, and proceeds towards the fundus. Using the tip of the hook diathermy, the surgeon should attempt to dissect one tissue plane at a time and take advantage of the "Champagne effect"; this is where the gallbladder mesentery is breached, and air enters to allow for easier visualisation of the correct dissection planes. Once a significant amount of the dissection has been completed, we advise that the assistant retracts the gallbladder towards the nine or ten o'clock position. Further dissection then allows for the creation of a "critical win- dow". Progress can then be made underneath the gallbladder; this is often referred to as the "under the bridge" technique. We advise the gallbladder is dissected off the cystic plate as much as possible before attention is turned to the cystic artery and cystic duct.

The surgeon should dissect out Calot's triangle so that the cystic duct and cystic artery can be seen entering/exiting the gallbladder. Ligating clips should be placed on each of these structures, three to the lower end of the duct and two to the artery. As such, two clips remain in situ when the duct is cut, and one remains on the artery. The gallbladder can then be dissected off the gallbladder fossa, placed in a bag, and removed. Haemostasis should be achieved, and the gallbladder fossa should be checked for bleeding prior to closure. We advise closure of the umbilical port under direct vision; this can be achieved by shifting the camera to the additional port.

\section{CONCLUSION}

The number of severely obese patients who undergo $L C$ is set to increase. Such a body habitus creates specific challenges which surgeons must be equipped to manage. We advise the use of an additional twelve-millimetre port in the left upper quadrant. This allows for the safe inferior retraction of the duodenum and reduces the risk of liver injury.

Informed Consent: Informed consents were obtained from patients.

Peer-review: Externally peer-reviewed.

Author Contributions: Concept - S.A., T.B.R.; Design - S.A., T.B.R.; Supervision - S.A.; Literature Search - T.B.R.; Writing Manuscript - T.B.R.; Critical Reviews - S.A.

Conflict of Interest: No conflict of interest was declared by the authors.

Financial Disclosure: The authors declared that this study has received no financial support.

\section{REFERENCES}

1. Reynolds JrW. The first laparoscopic cholecystectomy. JSLS 2001; 5(1): 89-94. [CrossRef]

2. Sutcliffe RP, Hollyman M, Hodson J, Bonney G, Vohra RS, Griffiths EA, et al. Preoperative risk factors for conversion from laparoscopic to open cholecystectomy: a validated risk score derived from a prospective U.K. database of 8820 patients. HPB (Oxford) 2016; 18(11): 922-8. [CrossRef]

3. Keaver L, Xu B, Jaccard A, Webber L. Morbid obesity in the UK: A modelling projection study to 2035. Scand J Public Health 2020; 48(4): 422-7. [CrossRef]

4. Tiong L, Oh J. Safety and efficacy of a laparoscopic cholecystectomy in the morbid and super obese patients. HPB (Oxford) 2015; 17(7): 6004. [CrossRef] 


\section{CERRAHI TEKNIK-ÖZET}

Turk J Surg 2021; 37 (4): 413-416

\section{Biz nasıl yapıyoruz: Yüksek obezitesi olan hastalarda laparoskopik kolesistektomi}

Thomas B. Russell, Somaiah Aroori

Plymouth NHS Trust Üniversite Hastaneleri, Hepatopankreatikobilier Cerrahi Kliniği, Plymouth, Birleşik Krallık

\section{ÖZET}

Obezitesi olan hasta sayısı artmaya devam ederken aynı artış trendi ağır obeziteli hastalarda da görülmektedir. Bu yüksek riskli hasta alt grubu, laparoskopik kolesistektomi esnasında cerraha ek zorluklar yüklemektedir. Bu işlemi gerçekleştiren her cerrahın dönebileceği güvenilir bir stratejiye sahip olması önemlidir. Bu makale, bizim yaklaşımımızı ortaya koymaktadır. Supra-umbilikal insizyon ile pnömopertoneum ulaşıldığında operasyona devam etmeden önce fasiyal sütür konulmasını tavsiye etmekteyiz. Bu işlem, yüksek kaliteli kapama sağlarken insizyonel herni oluşumunu ve kasıtsız olarak sebep olunan bağırsak hasarını da azaltmaktadır. Ayrıca, port yerleştirilmesinden önce daha ergonomik bir ortam yaratabilmek adına hastanın ameliyat masasında tekrar pozisyonlanmasını da önermekteyiz. Standart portlara ilaveten sol üst kadranda $12 \mathrm{~mm}$ 'lik ek bir port daha kullanmaktayız. Bu port ile fan retraktör içeri sokulabilir ve duodenum inferiyör olarak hafifçe çekilebilir. Bu, Calot diseksiyonu açısından uygun açıklığı sağlamakta ve muhtemelen yağlı bir karaciğere hasar riskini azaltmaktadır. Bu teknik, Calot diseksiyonu özellikle zorlayıcı olan obez olmayan hasta gruplarında ve örneğin gecikmiş kolesistektomi gibi durumlarda kullanılabilir.

Anahtar Kelimeler: Laparoskopik kolesistektomi, obez, morbid, ciddi, bariyatrik, günübirlik ameliyat

Doi: $10.47717 /$ turkjsurg.2021.5452 